\title{
Political Economy of Resettlement Planning and Beneficiary Selection in A1 and A2 Settlement Models in Zimbabwe Post 2000
}

\author{
Joyce Sifile1, Manase Kudzai Chiweshe², Patience Mutopo ${ }^{1}$ \\ ${ }^{1}$ Centre for Development Studies, Chinhoyi University of Technology, Chinhoyi, Zimbabwe \\ ${ }^{2}$ Department of Social and Community Development, University of Zimbabwe, Harare, Zimbabwe \\ Email: jsifile@yahoo.com, manasekudzai@gmail.com, mutopop@gmail.com
}

How to cite this paper: Sifile, J., Chiweshe, M.K. and Mutopo, P. (2021) Political Economy of Resettlement Planning and Beneficiary Selection in A1 and A2 Settlement Models in Zimbabwe Post 2000. Open Access Library Journal, 8: e7758. https://doi.org/10.4236/oalib.1107758

Received: July 14, 2021

Accepted: August 13, 2021

Published: August 16, 2021

Copyright $\odot 2021$ by author(s) and Open Access Library Inc.

This work is licensed under the Creative Commons Attribution International License (CC BY 4.0).

http://creativecommons.org/licenses/by/4.0/ (c) (i) Open Access

\begin{abstract}
The paper examines the political economy of resettlement planning, beneficiary selection and reasoning behind A1 and A2 in Zimbabwe post year 2000. The Fast-Track Land Reform Programme which was preceded by land occupations led by war veterans and some ruling party members of the Zimbabwe African National Union-Patriotic Front (ZANU-PF) was based on political imperatives in land allocation with little consideration of sound settlement planning and land use. The purpose of this paper is to have an understanding of the planning, beneficiary selection and reasoning behind the implementation of A1 and A2 models. The paper also examines the political and socio-economic imperatives that influenced beneficiary selection in Mashonaland West, Zimbabwe. The study used the multi-method approach. The study used a case study of Makonde district in Mashonaland West Province, Zimbabwe from A1 and A2 farmers. The study dwelt mainly on qualitative methodologies in order to get farmers' perceptions and feelings towards the issues around land distribution on the role of politics in resettlement planning and beneficiary selection. The qualitative approach was conducted through focus group discussion, in-depth interviews, key informants and participant observation. The self-administered questionnaires were distributed mainly to A2 farmers who were assumed to be literate. Secondary data were collected from the farmers' database of the Lands Department, waiting lists for both A1 and $\mathrm{A} 2$ farmers and also farmer application forms. The major finding of the study was that politics played a major role in land allocation and selection of beneficiaries. The war veterans and political leadership were part of the district and provincial lands committees responsible for the selection of beneficiaries. Land beneficiaries were passive participants in decision making; they lacked representation and were fearful of political leaders and war veterans.
\end{abstract}




\section{Subject Areas}

Human Geography

\section{Keywords}

A1 and A2 Models, Beneficiary Selection, Resettlement, Land, Politics and Fast Track

\section{Introduction}

The Fast-Track Land Reform Programme (FTLRP) in Zimbabwe was implemented with speed following land occupations led by veterans of the war of liberation in the 1970s. The spontaneous and often violent nature of the land occupation meant that there was little consideration of planning issues because the state was aiming at acquiring land to resettle many people in a short period of time. The emphasis of the programme was on allocating land to as many beneficiaries as they could despite agricultural potential. In some cases politicians gave instructions on the number of people to be settled regardless of carrying capacity and suitability of the land. This paper focuses on an area within the FTLRP which has received sparse academic coverage. It examines how the omission of this critical area due to the fast-paced nature of the FTLRP, is affecting the productivity of resettled farmers in Makonde district. The paper also examines the political and land use thinking around implementing A1 and A2 resettlement models. The Ministry of Agriculture, Lands, Water, Fisheries and Rural Resettlement introduced two resettlement models, the A1 which is the village model with a communal setup and self-contained form and the A2 model which has three forms which are the small, medium and large-scale commercial farms [1].

The arrival of the British in Zimbabwe in 1890 resulted in speedy social changes, especially the settlement patterns and land use systems which went through a radical transformation with an expectant effect on animal and social structures [2]. The Pioneer Column invaded vast lands in most parts of Mashonaland and this marked the initial occupation of land by white settlers [3]. The evicted families had to move in groups according to their chieftainships and they were not paid any compensation on their land and assets they might have left at their original homes. On contrary, Zimbabwe expressed through David Hasluck director of the CFU from 1984-2000 that since the land was grabbed from Zimbabweans' ancestors without any compensation and it was often chaotic and there was no one who recognised the violence from the colonial power the British must therefore live with the responsibility [4].

The history of land reforms in Zimbabwe has previously been debated in detail in many scholarly works [5] [6] [7] [8]. In this paper we provide a short overview that shows how political and economic imperatives have shaped deci- 
sions around land, land use and planning. At independence in 1980, the new black government inherited a racially skewed land ownership structure which was a major reason for a protracted war of liberation [9]. The new government thus sought to quickly respond to the land question by initiating what is now termed phase one resettlement system between 1980 and 1999. In the period 1980 to 1999 there were four models that were used in the placement of black farmers namely model A for planned villages, model B for socialist cooperatives, model C for out-growers linked to state farms and model D village range [10]. Model A was intended to address the de-congestion and welfare objectives, while model $\mathrm{B}, \mathrm{C}$ and $\mathrm{D}$ were designed to achieve agricultural commercialization. However, model A was more common and inevitably, beneficiaries of the first LRP carried out between 1980 and 1989 could not transform into fully fledged commercial agriculture, notwithstanding state support in the provision of agricultural inputs and infrastructure including roads and dams [10]. Masiiwa \& Chapungu (2004) [11] summarize the criteria dictated by the government in the selection of beneficiaries which were as follows: Overcrowded and landless people; poor and unemployed families with dependents between 18 and 55 years of age; Zimbabwean refugees who returned from war; experienced native farmers who were prepared to forego their land rights in communal areas and paid employment; and communal farmers who were holders of master farmer certificates. The model included some nucleated villages where each household was allocated residential stands in a planned village with an individual arable land and with a communal grazing area [12]. Model B had cooperatives formed by settlers with a communal type of living. All resources including land and equipment were jointly owned in form of cooperatives except for livestock which would be privately owned. The technical committee of the Inter-Ministerial Committee on Resettlement and Rural Development (IMCRD) recommended the removal of cooperatives from the second phase of Land Reform Programme framework as all land was planned either under model A1 or model A2.

By 1998, there was general despondency and disappointment over the pace of land acquisition and resettlement. Over the years, rural communities had continued to use various means to put pressure on the government for land redistribution such as squatting and poaching resources like firewood. The government responded in 1998 by convening a donors' conference as a means to find consensus and international support for land reform. The objectives of the donors' conference were meant to achieve a more orderly rational system of farming to come up with excellent land utilization and natural resources and an equitable access to all Zimbabweans despite gender, colour or creed. According to Masiiwa (2005) [13] the conference states that land which was identified for occupation was: Underutilized or derelict land; Land which belonged to absent landlords; Land which belonged to commercial farmers or companies with multiple farms; Farms exceeding maximum farm sizes with over 1500 hectares in regions 1 or 2; and land adjacent to communal areas. The people who were to ben- 
efit from this programme phase were those from overcrowded areas, the landless, those with the expertise (graduates from agriculture colleges) and other people with farming experience [13]. By 1999 however, the most of Zimbabwe's prime land was still under the hands of white farmers.

Mutasa (2015) [14] posits that there were several promises to resettle people through significant land reform programmes leading many Zimbabweans to get fed up with unfulfilled promises. Therefore some villagers and war veterans of war veterans invaded some white owned commercial farms. The war veterans organised themselves and took the matters and law into their own hands and started the land seizures gaining a lot of public support [14]. In separate studies in Chipinge by Zamchiya (2011) [15] and in Goromonzi by Marongwe (2011) [6] similar patterns of land invasions were observed. The government therefore allowed the takeovers by war veterans due to their huge support. The farms were taken by force without any prior warning and most farmers were given a one-day ultimatum to vacate the farms. The ruling party capitalized on the land issue to gain political mileage which was also fading due to the harsh economic situation prevailing in the country. Bond (2005) [16] argues that the land occupations were only benefiting the politically powerful and this destroyed agriculture. Zamchiya (2011) [15] argues that in Chipinge district in South-Eastern Zimbabwe, some successful A1 farmers were clients of ZANU-PF patronage network who used their political influence to gain access to labour farming inputs and land containing valuable export crops. Patronage took centre stage in beneficiary selection across the studied sites in Chipinge district.

In 2001 the Agritex move was largely a confirmation exercise of the pre-existing allocations rather than a radical change of the land structure. Some farm workers confronted the District Administrator and forced him to allocate plots to them. The DA put cards in his Agritex Sunhat and the farm workers randomly pick the number picked being the plot number. Some war veterans in Chipinge reinvented their identity as it became political currency in gaining access to land through land invasions and regularization of informal settlers [15]. There was no coordination of events during the invasions where 400 farms were occupied with some groups causing disruptions by slaughtering cattle and demanding transport from farmers [17]. Planning seems to have been a desk exercise which did not take infrastructure into cognisance. Most of the infrastructure in farms has been vandalized [18]. They pegged plots measured with tape measures and a group of invaders were carefully organized into cells run by base commanders [8]. Social service delivery has been a result of the dynamics of new resettlements and the political and ethical cleavages in the resettled areas has become very poor with people travelling long distances to acquire health facilities and schools in Kushinga, Lukhuluba and Zhaungwe wards in Vungu and Tongogara District in the Midlands Province [19]. There are still many people who saw these occupations as the only lasting solution to the white minority racism and also a way to resolve reluctance in promoting equitable distribution of land in the country. 
Chaumba, et al. (2003) [20] purport that there were the Provincial Lands Committees chaired by minister of State and District Lands Committees chaired by District Administrator in Masvingo province which were meant for beneficiary selection and land allocation. These committees were composed of civil servants, ruling party chairman, war veteran chairman, police, army, CIO, social welfare, chiefs, health and veterinary. A separate study [15] observed a similar pattern in Chipinge district of Manicaland Province. Party cells are also instrumental in the resettled farms. The farm village committees have been found in some resettled farms in Masvingo Province and Mazowe district playing a major role in controlling the farmers socially, economically and politically [21]. Marongwe (2011) [6] in his argument asserts that, in Goromonzi District, Mashonaland East Province the data gathered from field and the official secondary data from the governments audits indicates that the criteria for A2 beneficiary selection as prescribed by the policy which emphasized on land use productivity was ignored in practice. Zamchiya (2011) [15] concurs that in Chipinge bigger farms were allocated to a few civil servants and others who were politically connected. Those with weaker political ties with in ZANU-PF got smaller farms of between three and five hectares. It is indicated that the bulk of beneficiaries were drawn from the government elite or were supporters of the Zimbabwe African National Union, Patriotic Front (ZANU PF) which was the ruling party. The FTLRP was carried out basing on clienteles and rampant sponsorship such that land claims were channeled through clientelistic network superintended by ZANU-PF for its own political survival. Politicians used their political power to override council by laws and statutes ending up in the infringement of legal process which opened the way to illegal occupations [22]. Some scholars reveal that former farm workers did not have communal homes, land or jobs to fall back on yet they were illegible to be allocated land since they were not Zimbabwean citizens [23].

Most scholars in their studies use such categories as civil servants, traditional authorities, war veterans and ordinary people in beneficiary selection [15]. It has then become difficult for both government and scholars to disengage categories of settlers to come up with a summary that best represents who got what. The summary of categories of settlers which was used gives precedence to occupation and social status is bound to overlap as people have multiple identities. A businessman can double up as a civil servant. Therefore if such a template is not carefully informed by empirical data in terms of how people got land in particular context it can mislead interpretations [15]. In Masvingo the war veterans were spread across all categories [5]. They further argue that all war veterans on A1 village farms in their study sites were ordinary beneficiaries because they were unemployed and they had long dropped their war veterans' identity.

Despite several academic studies on the Fast Track Land Reform Programme (FTLRP) post 2000 in Zimbabwe there is a lack of studies focusing on the nature and thinking behind settlement types in resettlement farms and how they have 
influenced social and economic production on the farms. The rapid or fast track nature of the process preceded by chaoticfarm occupations has had multiple effects on the everyday happenings on the farms including conflicts over land use, farm infrastructure, natural resources and farm evictions. This study was undertaken on the perception that the resettlement programme did not consider a number of crucial issues when planning the AI and A2 farm settlements in Mashonaland West on land allocation strategies. The problems on settlement planning and beneficiary selection have been unresolved for a long period of time. The study therefore sought to determine the varied impacts of political economy of resettlement planning on A1 and A2 farms in Makonde District.

\section{Theoretical Framework}

Settlement planning is a strong tool for promoting equality and redressing injustices of colonialism. This research integrated the political economy and the sustainable livelihoods frameworks paying particular attention to the political economy of resettlement planning and beneficiary selection. The theoretical framework assists to understand nuances of settlement planning as a strong tool for promoting equitable distribution of land and issues of land allocation and beneficiary selection. The two frameworks resonate with the area of study and give varying perspectives on the same issues under study. The theoretical frameworks focus on the socio-economic and political factors which have influenced the creation of the farming models during the fast track land reform and their impacts on livelihoods. Ricardo [24] suggested that the political economy analytical frame mainly focuses on the relations and allocation of resources among the three groups which are the proprietor of land, owner of stock or capital and the labourers and a further look at how the resources are utilised. This study analyses how land policies in post-independence Zimbabwe have been structured by these relations and how farm model formulation have been made through political decisions and allocation of scarce resources among competing uses [25]. Caporaso and Levine (1992) [26] assert that, when political economy emerged in the eighteenth century, it helped people to understand and cope with a dramatic change in the system of wants satisfaction, both in the nature of wants and in the manner of production and distribution of goods for satisfying them. There are many approaches of the political economy model which are pivotal to the understanding of dynamics in the land reform settlement planning, land use and sustainable livelihoods issues around the reform exercise. The political elites engaged in predatory activities through the deployment of disorder and coercive force to both accumulate and distribute state resources.

In this study Sustainable Livelihood (SL) refers to capabilities, assets and activities required for people to ensure a comfortable quality of life, evidenced by their ability to meet their need for food, shelter, health, education and a sense of belonging taking cognisance of the natural resources at their disposal, without destroying their power to regenerate themselves [27]. If farmers under land 
reform have access to assets like land they will not automatically translate them to sustainable livelihoods but this will depend on the farmers' ability to utilise those resources. Some of the livelihood strategies include agricultural intensification like in crop and livestock production and livelihood diversification where farmers also focus on other sources of income apart from on-farm activities.

\section{Methodology}

The study utilised a multi-method approach which combined qualitative and quantitative research methods. The respective strengths of these two methodologies enabled the researchers to address important questions at different stages of research inquiry. The research adopted a case study design focused on Makonde district of Mashonaland West Province, Zimbabwe. This research design is applicable to quantitative research paradigm as well as to qualitative research, thus as this research integrates the two research paradigms, the case study is therefore ideal for a multi-method approach. The district lies along Harare-Chinhoyi and Kariba-Chirundu highway. The district is known for crop and livestock farming. Self-administered questionnaires were distributed to A2 farmers through systematic sampling and A1 farmers were selected through purposive sampling. All age groups were involved to get perceptions from both youth and adults who had stayed in the farms for more than ten years and even twenty. Women were involved in questionnaires, interviews and also in focus group discussions since they also participated in the FTLRP. Key informants were selected from Ministry of Agriculture, Lands, Water, Fisheries and Rural Resettlement, stakeholders from other government departments and village heads. There were six focus group discussions of six to eight members each which the researcher conducted.

\section{Findings and Discussion}

\subsection{Politics of Beneficiary Selection and Allocation}

There were an increased number of small, medium and large-scale farms during FTLRP and transfer of ownership from the minority white farmers to the majority black indigenous farmers [28]. Beneficiary selection and A1 allocation was the responsibility of the Provincial Lands Committee (PLC) and District Lands Committee (DLC). The A2 model was created for a cadre of black commercial farmers [29]. They further state that, it was observed that there was no uniform mechanism in beneficiary selection of the A2 settlement model where the offer letters were processed from National head office. Under the FTLRP scholars are divided on their interpretations of the land reform process. Marongwe (2011) [6] postulates that FTLRP was carried out basing on rampant sponsorship hence land claims were channeled through clientelistic network superintended by the ruling party for its own political survival. In Mazowe the ruling party structures were the main player on the fast-track programme, acquisition of land and resettlement [17]. Centre for Conflict Management and transformation (2014) [19] 
opines that in Mwenezi land in some instances was acquired through the concept of the economy of affection, especially if a person was related to the village head or to influential people like war veterans.

From the in-depth interview's respondents indicated those different categories of farmers were considered. It was established from the Department of Lands that there were ministerial policy guidelines which indicate that in land allocations, there was a quota for the war veterans and also a quota for the youth. The youth were considered from the ruling political party register. The party chairperson who attended the DLC meetings chose youth beneficiaries whose names were brought to the meeting for consideration. A woman youth from Boarder Gezi Youth Training College indicated that she was allocated under the youth although she was an adult. She stated that since she had participated in the National Youth service training scheme, her name was taken from their youth list by to the DLC then she was allocated land. Also, a war veteran indicated that he was allocated land under the war veterans' quota. Although the war veterans' quota was said to be considered under A1 farm model most war veterans who were interviewed in Makonde district indicated that they were allocated A2 farms under war veterans' quota. Pazvakavambwa and Hungwe (2009) [30] argue that the twenty percent quota allocation designated specifically for war veterans in all A1 farm models, yet some provincial governors continued to give the twenty percent quota to war veterans in A2 farms.

The responses from interviewees indicated that there were people from different organisations and institutions, civil servants and ordinary people who got land without any political backing through the application process. Scoones, et al. (2010) [5] have shown elsewhere that although informal political practice was at play most beneficiaries of FTLRP were ordinary citizens who actually benefited without being cronies. Lands officer in this study also indicated that A2 farmers were selected according to their potential in farming as they submitted their development plans, curriculum vitae, the equipment they had and their capacity in farming. The committee was supposed to consider war veterans quota, youth quota and women and the disabled as prescribed by the policy. There was need to indicate these quotas on the schedules which were submitted to the Minister of Lands for the production of A2 offer letters. Names of war veterans came through the War Veterans Association and the youth came through the Youth League but people with disabilities were largely excluded from benefiting.

The largest number of beneficiaries who got A2 farms from the in-depth interview results was ordinary people. These results from the in-depth interviews were authenticated by the self-administered questionnaires where a majority of the respondents were ordinary people who benefited from the selection with (30\%), followed by civil service (29\%), youth (18\%), war veteran's $(11 \%)$, women in their own right (5\%) and village heads (2\%). Mangachena (2003) [31] states that the FTLRP was aimed at fairly redistributing land to the highly marginalized communities without any favour. These findings are also in line with one of the 
donor conference agreement which states that poverty reduction will involve the selection of beneficiaries from the vulnerable groups like women, farm workers and the disabled, overcrowded areas, landless people and those with the skills and were gifted in farming. Whilst there is a semblance of fairness, a closer analysis shows that political decisions were made in selecting beneficiaries. One respondent from the in-depth interviews revealed that there was no clear distinction between the land occupations and formal allocations since the occupiers were later regularized and offered tenure documents formalising their occupation of the land. Most occupiers were aligned to war veterans, landless people and youths all loosely under the guidance of ZANU PF. According to one respondent "party cards were an advantage in accessing land since leaders usually asked for the ruling party card (ZANU PF) whenever there was a programme." Most leaders in the farming areas were from the war veterans and ruling party leadership. From the interviews people indicated that they were not forced to buy the party cards, but they had to buy in order to be recognised. It was revealed that the consideration of party card holders led some opposition party members to buy the ruling party cards for recognition in land access.

\subsection{Beneficiary Selection and Allocation Process for A1 and $A 2$}

The respondents from one group discussion indicated that they got their pieces of land on the onset of land reform. They were staying on base camps where they selected their chairpersons led by a team of war veterans, ruling party members and local villagers. This was also noted from previous literature that land occupations were followed by spontaneous and widespread farm occupations led by ZANU PF cadres, War Veterans and traditional leaders as well as some ordinary villagers from nearby communal areas, towns and also some farm workers [32]. They illegally settled on farms before they got offer letters then their chairman and war veterans who were in the committees took their names to the District Development Coordinator (DDC) where people were asked to pick some cards with plot numbers. Those numbers were later used in processing of the A1 temporary permits. The Agritex team then came later to demarcate the plots. Moyo, et al. (2009) [33] also state that some A1 land beneficiaries secured land through illegal occupations, and these were later regularized by the government of Zimbabwe. Another participant indicated that they occupied the land but further regularized their farms which automatically made them formal. "Isu takapinda pano zvejambanja tichibvisa murungu asi matsamba edu eminda akangovuya nemachairman edu isu tigere zvedu vuno saka takagariswa zviripamutemo nehurumende yedu" (We invaded the farm and managed to remove the white farmer then our chairpersons brought our A1 permits from the offices when we were on our farms which made us formally settled.)

All A1 temporary permits were signed from the DDC's office after the alloca- 
tion committee discussed the lists brought from the villages by chairpersons in order to facilitate the issuance of the A1 permits. The chairperson who was a member of the ruling party from the farms was handed over the temporary permits for their farms and distributed them to the plot owners. That is clientelism which was defined by Chamunogwa (2012) [28] as the exchange of services and resources for political support in form of votes. Lands Officer indicated that the form of allocation had caused a lot of problems and disharmony since the allocation was done in a retrospect process where the beneficiaries settled on the ground first and were allocated some plot numbers before land demarcation of land and layout production. The A2 farmers were allocated in a different way from the A1 farmers since they had to complete some land application forms where the names of successful applicants were later published in newspapers. One A2 interviewee stated that "I was first allocated land under ARDA however the plot became small for the projects which were being undertaken, so after making an application I was considered and allocated a larger plot of 260 ha in extent on Sterlingvale Farm." The Lands Officer revealed that "these days A1 applicants write application letters, and they are recorded on a waiting list which is renewed every year." He stated that when land becomes available beneficiaries will be allocated following the waiting list. One of the respondents from the in-depth interviews also indicated that the process is now different since the District Land Committee now considers people from their waiting lists and not those who settled illegally. The schedules are signed by four signatories (DDC, District Lands Officer (DLO), War veterans Chairperson and Ruling Party Representative) and submitted to the Provincial Lands office for the production of A1 temporary permits or for further processing of A2 schedules. The A1 temporary permits were no longer being signed by the DDC but by the Provincial Lands Officer since 2014.

\subsection{Beneficiary Selection and Allocation Was Guided by Government Policy}

From the in-depth interviews conducted, the settlers indicated that they were selected through the Land Committee which was the ministerial policy to show transparency in the selection. During the FTLRP the responsibility for beneficiary selection included diverse stakeholders such as traditional leaders (chiefs, headmen and village heads), Rural District Councils, District Administrators, Provincial Administrators, Provincial Governors, farmers' unions and NGOs [34], this was mainly aimed to remove any bias in the manner in which beneficiaries were to be selected. The results of this study from questionnaires show that $25 \%$ respondents strongly disagreed that beneficiary selection was guided by lands ministry policy, $14 \%$ disagreed, $21 \%$ were neutral while $21 \%$ agreed, $25 \%$ strongly agreed with this notion. The research contents that farmers had varying views concerning the way in which beneficiaries were selected and allocated. The diverse views of the farmers are discussed below: 


\subsection{Land Reform Program Benefited Ordinary Citizens, but Politicians Got Bigger Plots}

From the interviews, we conclude that the majority of ordinary people benefited. Moyo, et al. [7] [33] argue that the A2 beneficiary selection was done following some policy guidelines claiming that 82 per cent of the beneficiaries in their sample were formally allocated land by government. One respondent from in-depth interviews indicated that the only difference was on the size of the plots especially under A2. Ordinary people were mainly allocated A2 plots ranging from fifteen hectares in extent whereas some top politicians got as much as 100 to over 3000 hectares in extent. "Vakuru vakuru vangaratidza havo sevashoma vakawana minda iyi asi kuti ivo vaipiwa mazimunda akakurisa nevana vavo nehama neshamwari dzavo" (It may reflect as if a few top officials benefited but they got vast pieces of land together with their children, friends and relatives). This is an indication of neo-patrimonialism where there is corruption in land redistribution processes. Matamanda (2020) [22] stated that politicians used their political power to override council by-laws and statutes ending up in infringing legal processes which opened way to more land.

\subsection{Land Reform Program Changed the Lives of Beneficiaries}

It was also established from the respondents that, since they settled in the farms their lives had never been the same, and by comparing to the past, most of the things had changed for better especially on the basic needs like food, shelter and clothing. Farmers could now grow for consumption with extra for sale which could help them with the upkeep of their families. Most respondents revealed that they managed to buy farm equipment, build good brick under asbestos sheets houses and buy other family assets like television sets and furniture which they could never have managed to buy if they were not on the farms. Respondents confirmed that they were now sending their children to boarding schools where they acquired better education. One respondent at Portlet Farm opined that some people were looking down upon new farmers, but they now admire what farmers are doing. Another respondent also indicated that "From seeing what we are doing, most people were now impressed by the lives of farmers, resulting in many who want to engage into farming." This was proved by several piles of application forms observed at the Ministry of lands offices. It was revealed that the piles were only made between 2018 and 2020 and the office received almost 100 applications per day. Some forms were being handed in through the provincial district offices. The reason why the forms kept on piling was that there was no land readily available for allocation.

\subsection{Land Reform Program Redressed Colonial Imbalances}

A majority of the respondents from the self-administered questionnaire were of the view that, the land reform program managed to address colonial imbalances in the distribution of resources as many indigenous people got access to land in 
areas with good soils and favourable rainfall patterns. The political system generated different relations to the oppressive agriculture system of the colonial state [33]. The colonial state had implanted Zimbabwe into the world's capitalist eye although catering for the interests of white minority. The blacks were forced to work on the farms and mines for very little wages so that they could meet the colonial state's demands of excessive taxes. The responses from the self administered questionnaires indicated that $49 \%$ of the respondents agreed that colonial imbalances were addressed, 29\% strongly agreeing that colonial imbalances in the distribution of resources were addressed. Only $8 \%$ were not sure, another $8 \%$ disagreed and $6 \%$ strongly disagreed that the land reform program managed to address imbalances in the distribution of resources. One respondent revealed that land reform program managed to address colonial imbalances in the distribution of resources. "Takanga takasundirwa kumakan'a vamweo mumakomo mune dzimwe nzvimbo kusina mvura yakakwana tichingoita nzara gore negore" (We were moved to unproductive marginal areas on vleis, rocky and areas with erratic rainfall where we were exposed to droughts almost every year) one of the respondents emphasized. Another respondent also stated that "Vabereki vedu vaingopona nokushandira varungu mumapurazi muno asiiro ivhu riri redu taiona kunge isu hatingambozvikwanisi." (Our parents were commercial farm workers who survived through working for the white farmers, and we never thought we can do farming on our own.)

Scoones, et al. (2010) [5] had the same sentiments from their study whereby many people saw the occupations as the only lasting solution to the white minority racism and also as a way to resolve reluctance in promoting equitable distribution of land in the country. Mawere (2011) [35] also echoes that post land reform program, the majority of the black communities were resettled on the productive commercial farms, and this managed to address colonial imbalances on distribution of resources. However, from the interviews which were carried out by the farmers those who were in disagreement testified that there is still land inequalities in the sense that there are some big wigs who still hold very big pieces of land and the rural poor had no land they were languishing in poverty. They claim that government is not downsizing those farms although they are too big as per their agro-ecological region requirement.

\subsection{Politics of Resettlement Planning and Rationale behind $\mathbf{A} 1$ and $\mathrm{A} 2$ Settlement Type}

An Agritex officer for Makonde District as one of the key informants revealed that the reason for the government to form the models was for the placement of indigenous people. She added that, "In the 80's there were models $A, B, C$ and $D$ where model $A 1$ was for de-congestion and welfare while $B, C$ and $D$ were for agriculture commercialization." Shonhe (2018) [10] concurs that the government introduced four models; model A for planned villages, model B for socialist cooperatives, model $\mathrm{C}$ for out-growers linked to state farms and model D vil- 
lage range. However, model A was turned to model A1 and then $\mathrm{B}, \mathrm{C}$ and $\mathrm{D}$ changed to model A2 after the Donor Conference Agreement. The officer pointed out that most of the indigenous farmers who were in the native reserves were on marginal areas where they were not doing proper farming. The government of Zimbabwe drew its objectives from the donor conference agreement which focused on poverty reduction through beneficiary selection from vulnerable groups that involved women, the disabled, former farm workers, overcrowded areas and landless and also gender fairness was considered. The responses from the Lands officer also indicated that the A1 model was meant to relieve pressure from communal areas and eradicate poverty by allocating land to the poor therefore the issues for A1 beneficiaries were mainly handled on the ground by people who could assess what was happening to the prospective beneficiaries. Most invaders were A1 farmers who were further regularized were they had already occupied. A much earlier study by Matondi (2012) [36] outlines that; A1 Model was aiming at the decongestion of rural communities and also to provide land to the landless people in a village and self-contained model. The aim of the model A2 was to create small-scale and medium scale black indigenous farmers, allocated for commercial purpose to blacks with their paddocks and residential areas within their designated plots.

Key informants from Agritex and District Development Fund (DDF) indicated that the government plan was good but the way it was implemented through land occupations made it very difficult to do proper planning in trying to consider some aspects on the ground. They revealed that the people were haphazardly settled and did not have access to services such as communication networks, water, schools, shops and health facilities. In some instance it became difficult to locate villages close to their fields. The A1 village model was meant to make easy developments like schools, business centres there are sites which were left closer to villages however such a provision was not considered for the A2 farmers. The Lands officer responded that there were still problems within A2 farms where people want to site a school in a beneficiary's plot. He also pointed out that there was a lot of resistance from farmers in volunteering to offer sites for school construction for the community. This has forced most children from compounds and also for some farmers to travel very long distances to school and some even drop out from school. The planning in some cases did not consider the infrastructure which was left by white farmers so that the indigenous farmers were going to continue using. One A2 farmer was found with barns in the plot while the grading sheds were located in the next plot. This made it difficult for farmers to operate since the infrastructure which is supposed to work as one unit was shared to two farmers.

The two models were created by the government without much consultation from the beneficiaries. The technocratic control of the resettlement process sidelined the people on the ground and preferred what some respondents called "book knowledge" over what the rural communities knew about the land. 
Chaumba, et al. (2003) [20] have noted how land occupiers were sidelined by technocratic planners as the land occupations turned into Fast Track Land Reform Programme. The A1 model proved that it was good for those who did not have equipment and also those who needed land only for subsistence. It was observed that those who got land for subsistence were content with the activities that they were doing. The village head from Angwa ICA reflected that there was a mixed bag within the A1 farmers. "Muno mune vanorima chaizvo zvokutoti six hectares dziri kuvaitira diki uye vakatenga zvose zvokurimisa asi tozoitao vamwe vokuti ivavo vanongoda musha wokugara nokuti unotoona kuti zvokurima zviri kuvanetsa. Kuti munhu arime kunge aine zvokubatisa Zvakakwana” (There are some prominent A1 farmers who are finding the six-hectare plots to be too small since they have their own farming machinery then there are some who do not have anything for farming who only need a place to stay. There is need for a farmer to have enough machinery for proper farming to take place. Most of these people were leasing out their land to some good farmers. Therefore, the study revealed that there was supposed to have some small plots of less than six hectares for those who only liked subsistence since the aim of the FTLRP was to decongest the communal areas then smaller pieces of land for such people were supposed to be taken into consideration. The six-hectare plots would therefore be for those who did not have much potential to utilise A2 plots but who could utilise the whole six-hectare plots for both subsistence production and a bit extra for sale and also those who wanted to do horticultural activities. Since the A2 farms were meant for commercial production there was need to make these plots a bit bigger than the fifteen-hectare plots that some farmers got.

Some respondents indicated that $\mathrm{A} 1$ village farmers have their villages located far away from their fields. This made it difficult to move from the village every day to the fields where they arrived when they were already tired before they started working. These distances had distorted the model since some A1 farmers were found relocating to their plots leaving the village. One of the A2 respondents indicated that they were mainly affected by poverty such that they could not afford to buy inputs like certified seeds and fertilizers thereby leading to low productivity. This poverty in farmers has been triggered by late or non-payment from the Agricultural marketing institutions for example the Grain Marketing Board. That is why the government came up with the position on Joint ventures on underutilized farms and also those with irrigation infrastructure which was lying idle in both A1 and A2 farms. In response to the agriculture finance crisis the policy position of the "Zimbabwe is Open for Business" mantra entails the joint ventures and the latifundia [37].

\section{Conclusion}

The study indicated that politics played a major role in land allocation and selection of beneficiaries. The war veterans and political leadership were part of the 
district and provincial lands committees responsible for the selection of beneficiaries for both A1 and A2 farms. This has made it difficult to make proper settlement planning since the programme was done with speed. Some services were not easily accessible like schools and clinics. However land reform program managed to redress colonial imbalances in the distribution of resources from an oppressive agriculture system of the colonial state. Most indigenous black people were allocated good fertile land. The new beneficiaries are showing satisfaction with the introduction of land reform; they indicated that there is a positive change in their lives. Some farmers who were moved to A1 plots in order to relieve pressure from communal areas were only producing for subsistence. The A1 plots were found to be too big for them hence a model with smaller plots could be ideal for them. There are some farmers who have managed to buy some farm equipment and as a result they are finding their plots to be small.

\section{Funding Acknowledgements}

The authors did not receive financial support for research, authorship and/or publication of this article.

\section{Conflicts of Interest}

The authors declare no conflicts of interest.

\section{References}

[1] Chiremba, S. and Masters, W. (2011) The Experience of Resettled Farmers in Zimbabwe. African Studies Quarterly, 7, 97-117. http://web.africa.ufl.edu

[2] Andreucci, M.R. (2018) Colonialism: The Bone of Contention Was Land. The Patriot.

[3] Zvobgo, C.J. (2009) A History of Zimbabwe, 1890-2000 and Postscript, Zimbabwe, 2001-2008. Cambridge Scholars Publishing, Newcastle upon Tyne.

[4] Ankomah, B. (2003) The Land Has Come Back. New African, 415, 12-15.

[5] Scoones, I., Marongedze, N., Mavedzenge, B., Murimbarimba, F., Mahenehene, J. and Sukume, C. (2011) Zimbabwe's Land Reform: Challenging the Myths. The Journal of Peasant Studies, 38, 967-993. https://doi.org/10.1080/03066150.2011.622042

[6] Marongwe, N. (2011) Who Was Allocated Fast Track Land, and What Did They Do with It? Selection of A2 Farmers in Goromonzi District, Zimbabwe and Its Impacts on Agricultural Production. Journal of Peasant Studies, 38, 1069-1092. https://doi.org/10.1080/03066150.2011.636483

[7] Moyo, S. and Yeros, P. (2005) Land Occupations and Land Reform in Zimbabwe: Towards the National Dermocratic Revolutionin. In: Moyo, S. and Yeros, P., Eds., Reclaiming the Land: The Resurgence of Rural Movement in Africa, Asia and Latin America, Zed Books, London, 165-206. https://doi.org/10.5040/9781350222175.ch-006

[8] Mkodzongi, G. (2018) Peasant Agency in Changing Agrarian Situation in Central Zimbabwe: The Case of Mhondoro Ngezi. Agrarian South: Journal of Political Economy, 7, 188-210. https://doi.org/10.1177\%2F2277976018779859 
[9] Mkodzongi, G. and Spiegel, S. (2019) Artisanal Gold Mining and Farming: Livelihood Linkages and Labour Dynamics after Land Reforms in Zimbabwe. The Journal of Development Studies, 55, 2145-2161. https://doi.org/10.1080/00220388.2018.1516867

[10] Shonhe, T. (2018) The Political Economy of Agricultural Commercialisation in Zimbabwe. APRA Working Paper No. 12, Future Agricultures Consortium, Brighton.

[11] Masiiwa, M. and Chapungu, L. (2004) Land Reform Programme in Zimbabwe: Disparity between Policy Design and Implementation. In: Masiiwa, Ed., Post Independence Land Reforms in Zimbabwe Controversies and Impact on the Economy, Friedrich Ebert Stifung and Institute of Development Studies, Harare, 1-24.

[12] Chambati, W. (2001) A Review of Land Reallocation in Zimbabwe (1980-2000) Association of Energy Engineers, Harare.

[13] Masiiwa, M. (2005) The Fast Track Resettlement Programme in Zimbabwe: Disparity between Policy Design and Implementation. The Round Table, 94, 217-224. https://doi.org/10.1080/00358530500082916

[14] Mutasa, C. (2015) A Brief History of land in Zimbabwe 1890-Today, Focus on Land in Africa. World Resource Institute, Washington DC.

[15] Zamchiya, P. (2011) A Synopsis of Land and Agrarian Change in Chipinge District, Zimbabwe. Journal of Peasant Studies, 38, 1093-1122. https://doi.org/10.1080/03066150.2011.633703

[16] Bond, P. (2005) Zimbabwe's Hide and Seek with the IMF. Review of African Political Economy, 32, 609-619.

[17] Moyo, S. (2002) Peasant Organisations and Rural Civil Society in Africa: An Introduction. In: Moyo, S. and Ramdhane, B., Eds., Peasant Organisations and Dermocratisation in Africa, Council for the Development of Social Science Research in Africa, Dakar, 365.

[18] Utete, C. (2003) A Report of the Presidential Land Review Committee on the Implementation of the Fast Track Land Reform Programme 2000-2002. Vol. 2, Government Of Zimbabwe, Harare.

[19] Centre for Conflict Management and Transformation (2014) Challlenges to Social Service Delivery in Zimbabwe's Resettled Areas. Centre for Conflict Management and Transformation, Harare.

[20] Chaumba, J., Scoones, I. and Wolmer, W. (2003) From Jambanja to Planning: The Reassertion of Technocracy in Land Reform in South-Eastern Zimbabwe? The Journal of Modern African Studies, 41, 533-554. https://doi.org/10.1017/S0022278X03004397

[21] Chiweshe, M.K. (2011) Farm Level Institutions in Emergent Communities in Post Fast Track Zimbabwe: A Case of Mazowe District, CODESRIA-LIBRARY. Doctoral dissertation, Rhodes University, Makhanda (Grahamstown).

[22] Matamanda, A.R. (2020) Battling the Informal Settlement Challenge through Sustainable City Framework: Experiences and Lessons from Harare, Zimbabwe. Development Southern Africa, 37, 217-231. https://doi.org/10.1080/0376835X.2019.1572495

[23] Mutopo, P. (2011) Women's Struggles to Access and Control Land and Livelihoods after Fast-Track Land Reform in Mwenezi District, Zimbabwe. Journal of Peasant Studies, 38, 1021-1046. https://doi.org/10.1080/03066150.2011.635787

[24] Ricardo, D. (1817) The Theory of Comparative Advantage. In: Ricardo, D., Vol. 1 
Ed. By Pierro Sraffa with Collaboration of M.H. Dobb, Principles of Political Economy and Taxation, Cambridge University Press, Cambridge, London.

[25] Hall, R. (2011) The Politics of Land Reform in Post Apartheid South Africa. Review of African Political Economy, 31, 213-227. https://doi.org/10.1080/0305624042000262257

[26] Caporaso, J.A. and Levine, D.P. (1992) Theories of Political Economy. Cambridge University Press, Cambridge. https://doi.org/10.1017/CBO9780511840197

[27] DFID (Department for International Development) (2000) Sustainable Livelihoods Guidance Sheets. Department for International Department, London.

http://www.livelihoods.org/info/info-guidance sheets.html

[28] Chamunogwa, A.R. (2012) Political Economy Analysis of Fast Track Land Reform Programme in Zimbabwe. Unpublished MA Thesis, University of Sussex, Sussex.

[29] Hanlon, J., Manjengwa, J. and Smart, T. (2013) Zimbabwe Takes Back Its Land. Jacana Press, Johannesburg.

[30] Pazvakavambwa, S. and Hungwe, V. (2009) Land Redistribution in Zimbabwe. In: Binswanger-Mkize, H.P., Ed., Agricultural Land Redistribution: Towards a Greater Consensus, World Bank, Washington DC, 137-165.

[31] Mangachena, L.M. (2003) The Situation of Commercial Farm Workers after Land Reform in Zimbabwe. A Report Prepared for the Farm Community Trust of Zimbabwe, Center for Intelligent Information Retrieval, London.

[32] Nyawo, V.Z. (2014) Zimbabwe Post-Fast Track land Reform Programme: The Different Experiences Coming through. International Journal of African Renaissance Studies- Multi-, Inter- and Transdisciplinarity, 9, 36-49.

https://doi.org/10.1080/18186874.2014.916858

[33] Moyo, S., Chambati, W., Murisa, T., Siziba, D., Dangwa, C. and Nyoni, N. (2009) Fast Track Land Reform Baseline Survey in Zimbabwe: Trends and Tendencies, 2005/06. Africa Institute for Agrarian Studies, Harare.

[34] Roth, M. and Gonese, L. (2003) Land Reform Programme in Zimbabwe: Disparity between Policy Design and Implementation. In: Masiiwa, M., Ed., Post-Independence Land Reform in Zimbabwe. Controversies and Impact in the Economy. Friedrich Ebert Stiftung and Institute of Development Studies, University of Zimbabwe, Harare.

[35] Mawere, M. (2011) African Belief and Knowledge Systems: A Critical Perspective. African Books Collective, Oxford.

[36] Matondi, P.B. (2012) Zimbabwe's Fast Track Land Reform. Zed Books Ltd., London. https://doi.org/10.5040/9781350224209

[37] Mazwi, F., Tekwa, N., Chambati, W. and Mudimu, G. (2018) Locating the Position of Peasants under the "New Dispensation": A Focus on Land Tenure Issues. Policy Brief, No. 3, Sam Moyo African Institute of Agrarian Studies, Harare. 